\title{
Evaluation of biosimilar trastuzumab MYL-14010 in HER2-positive early-stage and metastatic breast cancer in real-life data
}

Kadir Eser ( $\nabla$ drkadireser@gmail.com )

MERSIN EDUCATION AND RESEARCH HOSPITAL https://orcid.org/0000-0001-8666-6177

Emel Sezer

Vehbi Erçolak

Ali İnal

Research Article

Keywords:

Posted Date: December 21st, 2021

DOI: https://doi.org/10.21203/rs.3.rs-1146217/v1

License: (c) (i) This work is licensed under a Creative Commons Attribution 4.0 International License.

Read Full License 


\section{Abstract}

Background The trastuzumab biosimilar MYL-14010 has demonstrated equivalent efficacy and comparable safety to reference trastuzumab (RTZ) in clinical trials of human epidermal growth factor receptor 2 (HER2)-positive metastatic breast cancer (MBC) as non-dual HER2 therapy. Here, we present the first real-world comparison of MYL-14010 versus RTZ with single/dual HER2-targeted therapy for the neoadjuvant, adjuvan and palliative first-/second-line treatment with HER2-positive early breast cancer (EBC) and metastatic breast cancer (MBC) patients in two tertiary hospitals in Turkey.

Methods We retrospectively investigated medical records in the Severance Breast Cancer Registry in Turkey. We identified patients with HER2-positive EBC $(n=159)$ who had received neoadjuvant chemotherapy $(n=92)$ with RTZ or MYL-14010 \pm pertuzumab and adjuvant chemotherapy $(n=67)$ with RTZ or MYL-14010 plus taxan between january 2018 and jun 2021. Stage IV MBC $(n=53)$ who had received palliative first-line treatment with RTZ or MYL-14010, and docetaxel \pm pertuzumab (THP) or second-line treatment with RTZ or MYL-14010, and taxan between january 2018 and jun 2021. Primary endpoints were pathological complete response in neoadjuvant grup (pCR) and progression-free survival (PFS) in adjuvant and metastatic grup. Secondary endpoints in the metastatic patient group (MBC) was overall response rate (ORR), disease control rate (DCR) and cardiac safety.

Results The rate of achieving pCR in the group receiving neoadjuvant chemotherapy was similar between MYL and RTZ (62.7\% [37/59] and 55.9\% [19/34] p=0.509). Median PFS similar in EBC-adjuvant group, 1224-36 months PFS respectively $96.3 \%, 84.7 \%, 71.5 \%$ in patients with MYL and $100 \%, 88.5 \%, 64.8 \%$ in patients with RTZ (95\% Cl p=0.577). Median PFS similar in metastatic group, 23.0 (9.8-16.1) months in patients with MYL-14010 and 23 (19.9-26.0) months in patients with RTZ (95\% Cl p=0.270). The ORR, DCR, and cardiac safety profiles did not also show significant difference efficacy outcomes between two groups.

Conclusion These real-world data suggest that biosimilar trastuzumab MYL-14010 has similar effectiveness and cardiac safety to RTZ in HER2-positive EBC and MBC patients when administered as part of single/dual HER2-targeted therapy with chemotherapy in the neoadjuvant, adjuvant or palliative setting.

\section{Introduction}

Development of new biological agents difficult and pricey, which can result in high drug costs [1]. Therefore, despite their effectiveness, these drugs cannot be used for patients in need in some countries due to the high costs [1]. These disadvantages can be partially reduced by the administration of biosimilars [1]. A biosimilar is very similar to a drug already in use, in addition, it has no clinically significant difference with the original or reference product in purity, safety and efficacy [1]. However, biosimilars are generally more cost-effective than reference products. Moreover, the applicability of biosimilar is likely to increase the accessibility of the treatments safety and effectively 
Breast cancer is the most frequently cancer and most frequently reason of cancer death in women around the world [2-4]. Human epidermal growth factor receptor 2 (HER2) is overexpressed in approximately $25 \%$ to $30 \%$ of breast cancers $[5,6]$. Trastuzumab is a humanized IgG1 mAb targeting HER2 [5]. The combination of chemotherapy (CT) and trastuzumab has been demonstrated to increase disease-free survival (DFS) and overall survival (OS) in HER2-positive early stage and metastatic breast cancer ( $\mathrm{mBC}$ ) [7-10]. Trastuzumab is also approved for metastatic gastric or gastroesophageal junction adenocarcinoma after confirmation of HER2 positive breast cancer.

Several currently in use biosimilars of trastuzumab have been developed, including MYL-14010 (Ogivri®; Viatris Inc, Zurich, Switzerland)[11], CT-P6 (Herzuma ${ }^{\circledR}$; Celltrion Inc., Incheon, Republic of Korea) [12, 13], SB3 (Ontruzant ${ }^{\circledR}$; Samsung Bioepis Co., Ltd) [14] ABP 980 (Kanjinti ${ }^{\circledR} ;$ Amgen) [15] and PF-05280014 (Trazimera ${ }^{\circledR}$; Pfizer) [16]. MYL-14010 (Trastuzumab-dkst) has the same amino acid sequence with trastuzumab (Herceptin $\circledast$; Genentech, Inc, South San Francisco, CA) [17]. The similarity between MYL14010 and reference trastuzumab (RTZ) sourced both from the United States and Europe, was demonstrated in physicochemical, preclinical, and pharmacokinetic studies $[18,19]$. The combination of MYL-14010 versus trastuzumab with taxane-based chemotherapy as first-line therapy in MBC was compared in the phase 3 HERITAGE trial [11]. The overall response rate (ORR) at 24 weeks, which was the primary endpoint, was equivalent between the biosimilar and RTZ groups [11], thus MYL-14010 is approved in the United States and Europe. At the end of 24 weeks, patients with stable or responsive disease continued on maintenance mAb monotherapy until progression at the HERITAGE trial [11].

Demonstrating long-term safety and efficacy of biosimilar drugs in larger patient populations, including results in neo/adjuvan settings and in combination with other treatments makes real-world studies an important complement to clinical studies. A good example is the increasing use of RTZ in combination with pertuzumab (Perjeta ${ }^{\circledR}$; Genentech) as part of dual HER2-targeted therapy. In HER2-positive EBC and MBC double HER2- targeting with trastuzumab and pertuzumab plus CT has been demonstrated to develop clinical responses compared to trastuzumab plus CT alone [20-22]. However, there is no clinical study with MYL-14010 in single/dual combination in early stage disease and dual combination in advanced disease.

The purpose of our study is to contribute to the literature to complete the missing data (efficacy and safety data) in the early and advanced stages, as well as to present the real-life data of myl-14010.

\section{Material And Method}

In this study, medical data were collected retrospectively from Mersin University Medical Faculty Medical Oncology Department and Mersin City Training-Research Hospital Medical Oncology Department. Patients with HER2 positive EBC as those who received neoadjuvant/adjuvant chemotherapy between January 2018 and June 2021. HER2-positive MBC was defined as newly diagnosed de novo or recurrently patients who received palliative chemotherapy between January 2018 and June 2021. 
American Joint Cancer Breast Cancer Staging Committee according to the seventh edition classification, EBC were defined as clinical stage II-III. In the MBC group, eligible patients had previously received and did not receive palliative therapy in advanced disease were included.

\section{Prosedures}

In the non-metastatic group, 2 different protocols were applied in those receiving neoadjuvant therapy: patients who received taxan+trastuzumab( $8 \mathrm{mg} / \mathrm{kg}$ at first cycle, $6 \mathrm{mg} / \mathrm{kg}$ at 2-4. cycles) after 4 cycles of AC(Adriamicin $60 \mathrm{mg} / \mathrm{m} 2$, Cyclophosphamide $600 \mathrm{mg} / \mathrm{m} 2,21$ day cycle) or patients who received 4 cycles taxan+trastuzumab (8mg/kg at first cycle, $6 \mathrm{mg} / \mathrm{kg}$ at 2-4. cycles)+pertuzumab (840 $\mathrm{mg}$ at first cycle, $420 \mathrm{mg}$ at 2-4. cycle) after 4 cycles of AC. There was no statistical difference between the groups in terms of MYL-14010 and RTZ usage rates. Adjuvant therapy was applied as 4 cycles AC followed by 4 cycles of taxan+trastuzumab followed by a single trastuzumab completion to 1 year.

In the metastatic group: patients receiving taxan+trastuzumab after $4 \mathrm{AC}$ or patients receiving taxan+trastuzumab+pertuzumab. There was no statistical difference between the groups in terms of MYL-14010 and RTZ usage rates. Pertuzumab and MYL-14010 or RTZ were given until disease progression or unmanaged toxic state. Pertuzumab, docetaxel and RTZ or MYL-14010 were given in the same doses in the metastatic group as in the neoadjuvant group.

\section{Outcome Measures}

Primary endpoints were pathological complete response in neoadjuvant grup (pCR) and progression-free survival (PFS) in adjuvant and metastatic grup, pCR was examined locally at the center of surgery. Absence of invasive tumor cells in the primary tumor and in the axillary lymph node was defined as pCR. Median PFS is the time from the start of palliative systemic therapy containing MYL or RTZ to the day the progression is documented.

Secondary endpoints in the metastatic patient group (MBC) was overall response rate (ORR), and disease control rate (DCR). ORR is the sum of complete response (CR) and partial response (PR) according to RECIST 1.1. DCR is the sum of CR, PR, stable disease (SD) according to RECIST 1.1.

Cardiac safety was a secondary endpoint in neoadvuvant, adjuvant and metastatic grup. $\geq 10$ percentage point decrease in LVEF from baseline in any condition or $<50 \%$ LVEF reduction at any time was defined as an cardiac side effect.

\section{Statistical Analysis}

Differences in PCR, ORR, and DCR between the RTZ and MYL-14010 treatment groups were evaluated by chi-square or fischer's exact test. For calculating PFS, generating survival curves and log-rank testing, Kaplan-Meier method was used. The statistical difference was considered significant when the P-value was $<0.05$. 


\section{Results}

The total number of patients in our study is 212 . Of a total of 159 female patients with HER2 positive EBC, 92 patients received neoadjuvant therapy followed by surgery and 67 patients received adjuvant therapy after surgery. In neoadjuvant therapy patients receiving MYL $(n=59,64.1 \%)$ and patients receiving RTZ ( $n=33,35.9 \%$ ) baseline characteristics were similar. In adjuvant therapy, patients receiving MYL $(n=27,40.2 \%)$ and patients receiving RTZ $(n=40,59.8 \%)$ baseline characteristics were similar.

In our study, we followed a total of 53 HER2 positive metastatic patients with recurrent or de novo stage IV. MBC patients who received palliative treatment between January 2018 and June 2021, chemotherapy containing trastuzumab some of in the 1 st line or some in the $2 \mathrm{nd}$ line. Those who received treatment in the 1 st line received THP, those who received treatment in the $2 \mathrm{nd}$ line received $\mathrm{TH}$. These rates were similar in the MYL (1. line 16\%, 2. line $84 \%$ ) and RTZ(1. line 17.9\%, 2. line $82.1 \%$ ) groups. Patients receiving MYL $(n=28,52.9 \%)$ and patients receiving RTZ $(n=25,47.1 \%)$ baseline characteristics were similar. Distant lymph nodes, bone, lung and liver are the most common sites of metastasis.

\section{Effectiveness of EBC and MBC Groups}

The rate of achieving $\mathrm{pCR}$ in the group receiving neoadjuvant chemotherapy was similar between MYL and RTZ, there was no statistical difference (Figure 1). The PCR rate was $62.7 \%(37 / 59)$ in the group receiving MYL and 55.9\% (19/34) in the group receiving RTZ ( $p=0.509)$. The PCR rate was similar in the hormone positive group receiving the neoadjuvant, in the group receiving MYL $(58.1 \%, 18 / 31)$ and RTZ $(52.6 \%, 10 / 19)$. The PCR rate in the hormone negative group receiving neoadjuvant was similar in the group receiving MYL $(67.9 \%, 19 / 28)$ and RTZ $(64.3 \%, 9 / 14)$.

Median PFS similar in EBC-adjuvant group, $12-24-36$ months PFS respectively $96.3 \%, 84.7 \%, 71.5 \%$ in patients with MYL and $100 \%, 88.5 \%, 64.8 \%$ in patients with RTZ $(95 \% \mathrm{Cl} \mathrm{p}=0.577)$

Median PFS similar in metastatic group, 23.0 (9.8-16.1) months in patients with MYL-14010 and 23 (19.9-26.0) months in patients with RTZ (95\% Cl p=0.270) (Figure 2). In the HR positive group, PFS was not reached and 26 months (23.9-28.0) (95\% Cl p=0.387), respectively, in those with MYL and RTZ, no statistically significant difference. In the HR negative group, there was no statistically significant difference in PFS in MYL and RTZ patients at 16 (12.7-19.2) months, 12 months (8.6-15.3) $(95 \% \mathrm{Cl}$ $p=0.376)$ respectively. There was no statistically significant difference in terms of ORR in MYL $(84.0 \%)$ and RTZ (78.6\%) ( $p=0.555)$. There was no statistically significant difference in terms of DCR in MYL $(92.0 \%)$ and RTZ (89.3\%) $(p>0.555)$

\section{Cardiac and Drug Reaction Safety}

In EBC cohort, the rate of LVEF did not differ between the two treatment groups before neoadjuvant chemotherapy (mean [95\% Cl] LVEF: MYL: 60.4\% [50.0-65.0] versus RTZ: 61.8\% [60.0-68.0]; P=0.134). After neoadjuvant chemotherapy, 5/59 (8.4\%) patients showed a decrease in LVEF of $\geq 10$ percentage 
points from baseline in the MYL, compared with 6/33 (18.1\%) patients in the RTZ ( $P=0.193) .1$ patients in RTZ and 1 patient inMYL showed a decrease in LVEF to $<50 \%$, both of them are reversible.

In EBC cohort, the rate of LVEF did not differ between the two treatment groups before adjuvant chemotherapy (mean [95\% CI] LVEF: MYL: 60.8\% [52.0-65.0] versus RTZ: 62.5\% [60.0-68.0]; P=0.150). After adjuvant chemotherapy, $3 / 27$ (11.1\%) patients showed a decrease in LVEF of $\geq 10$ percentage points from baseline in the MYL, compared with $3 / 40(7.5 \%)$ patients in the $R T Z(P=0.679) .1$ patients in RTZ treatment group showed a decrease in LVEF to $<50 \%$, but it was reversible.

In the metastatic group, LVEF decreased by more than $10 \%$ in $5 / 25(20 \%)$ patients in the MYL group and $4 / 28(14.2 \%)$ patients in the RTZ group ( $p=0.71$ ). In this group, no patients' LVEF decreased to $<50$ in the MYL and RTZ group.

Skin reactions predominated most of infusion-related drug reactions (IRDR) in our trial. The incidence of IRDR in neoadjuvant group was similar in MYL $(5 / 59,8.4 \%)$ and RTZ $(1 / 33,3 \%)(p=0.41)$. The incidence of IRDR in adjuvant group was similar in MYL $(3 / 27,11.1 \%)$ and RTZ $(4 / 40,10 \%)(p=0.59)$. The incidence of IRDR in metastatic group was similar in MYL $(2 / 25,8 \%)$ and RTZ $(2 / 28,7.1 \%)(p=0.41)$.

\section{Discussion}

To our knowledge, this is the first study to include real-life data on the treatment of MYL-14010. Phase 3 randomized controlled trial of MYL-14010 did not include neoadjuvant and adjuvant patients, only includes metastatic patients (they also did not receive pertuzumab combination therapy) [11]. In biosimilar therapy, showing similar treatment response efficacy in metastatic disease is sufficient to obtain approval for use [23]. Our study is the first in the literature in that MYL-14010 includes neoadjuvant/adjuvant therapy similarity efficacy and safety data in addition to metastatic disease.

In our study, the PCR ratio of those who received MYL-14010 (62.7\%) and RTZ (55.9\%) were similar in neoadjuvant treatment. PCR rates differ according to the chemotherapy combination received by the patients. In both MYL-14010 and RTZ group, 2/3 of our patients received AC+taxan, 1/3 $A C+\operatorname{taxan+pertuzumab.~The~PCR~rates~in~our~patients~are~similar~to~the~study~of~the~chemotherapy~}$ combination in the relevant literature (without pertuzumab 64.7\%, with pertuzumab $61.8 \%$ in different trials) $[24,25]$.

In addition to reflecting real-life data, our study shows that MYL-14010 is as effective as RTZ in the combination treatment with pertuzumab in metastatic HER2 positive patients. In the CLEOPATRA study, the addition of pertuzumab to first-line trastuzumab-docetaxel palliative treatment in HER2 positive metastatic BC was compared docetaxel-trastuzumab, PFS was 18.5 months vs 12.4 months $(p<0.001)$, OS was 56.5 months vs 40.8 months ( $<<0.001)$, respectively was found. The ORR rate in CLEOPATRA study was $80.1 \%$ with pertuzumab, $69.3 \%$ without pertuzumab [22]. Most of the patients in our study received treatment with pertuzumab. This is consistent with the proportion of patients who received the combination of pertuzumab+MYL-14010 (82\%) or +RTZ (80\%) in our study. 
The cardiotoxic effect of trastuzumab use has been known for a long time [10], and it often causes an asymptomatic decrease in LVEF. Serious cardiac toxicity was not observed in any patient in our study. 2 of the patients who received neoadjuvant (1 MYL-14010, 1 RTZ) and 1 adjuvant therapy (with MYL14010) had LVEF $<50$. This low cardiotoxicity is comparable to the rate of RTZ in the neoadjuvant study without pertuzumab and the study with pertuzumab [24].

No patients had LVEF $<50$ in metastatic patients in our study. This rate is better than the HERITAGE (12\%) and the CLEOPATRA $(6.1 \%)$ study $[22,26]$.

İn our study, there was no significant difference between MYL-14010 (8.4\%, 11.1\%, 8\%) and RTZ (3\%, $10 \%, 7.1 \%)$ groups for IRDR in neoadjuvant, adjuvant and metastatic patients, respectively $(\mathrm{p}=0.41$, $\mathrm{p}=0.59, \mathrm{p}=0.55$ ). Rugo HS at al. reported this rate (rash in the foreground) $8.9 \%$ and $10.2 \%$ in $\mathrm{MYL}$ and RTZ grup [26], so it shows similarity to our rates.

One of the important aspects of our study is the examination of large patient populations and different stages of BC disease. This study is the only and unique data in the literature due to the absence of neoadjuvant and adjuvant studies of MYL-14010 and absance of pertuzumab combination study in metastatic disease.

One of the limitations of our study is retrospective nature and the heterogeneity of the patients in the treatment arms. Therefore, prospective studies with larger patient populations are required. The second limitation is the short follow-up period in metastatic patient groups.

Biosimilars are biological products that are highly similar in safety, efficacy, and potency to the original product. The development of the biosimilar pharmaceutical industry is necessary due to rising drug price costs and global reach [27]. A study conducted in China showed that the use of RTZ is higher in rich countries than in poor countries, and accordingly, survival is better in both the early and metastatic stages [28]. As in previous studies $[1,11,26,29]$, our study has shown that biosimilar drugs are as effective and safe as RTZ. In this way, drug-expenditure will decrease and access to effective treatments will be easier. Our real-life study has shown that MYL-14010 has similar efficacy and safety as RTZ in neoadjuvant, adjuvant, and metastatic therapy as first- or second-line therapy, with or without pertuzumab combination therapy.

\section{References}

1. Lammers, P., et al., Barriers to the Use of Trastuzumab for HER2+ Breast Cancer and the Potential Impact of Biosimilars: A Physician Survey in the United States and Emerging Markets. Pharmaceuticals, 2014. 7(9).

2. Beslija, S., et al., Third consensus on medical treatment of metastatic breast cancer. Annals of Oncology, 2009. 20(11): p. 1771-1785. 
3. Key, T.J., P.K. Verkasalo, and E. Banks, Epidemiology of breast cancer. The Lancet Oncology, 2001. 2(3): p. 133-140.

4. World Health Organization. International Agency for Research on Cancer GLOBOCAN 2012: estimated cancer incidence, mortality and prevalence worldwide in 2012. 2012 [cited 20171 November ]; Available from: http://globocan.iarc.fr/Pages/DataSource_and_methods.aspx.

5. Eisenbeis, A.M. and S.J. Grau, Monoclonal antibodies and FC fragments for treating solid tumors. Biologics: targets \& therapy, 2012. 6: p. 13.

6. Iqbal, N. and N. Iqbal, Human Epidermal Growth Factor Receptor 2 (HER2) in Cancers: Overexpression and Therapeutic Implications. Molecular Biology International, 2014. 2014: p. 852748.

7. Perez, E.A., et al., Trastuzumab Plus Adjuvant Chemotherapy for Human Epidermal Growth Factor Receptor 2-Positive Breast Cancer: Planned Joint Analysis of Overall Survival From NSABP B-31 and NCCTG N9831. Journal of Clinical Oncology, 2014. 32(33): p. 3744-3752.

8. Piccart-Gebhart, M.J., et al., Trastuzumab after adjuvant chemotherapy in HER2-positive breast cancer. New England Journal of Medicine, 2005. 353(16): p. 1659-1672.

9. Slamon, D., et al., Adjuvant Trastuzumab in HER2-Positive Breast Cancer. New England Journal of Medicine, 2011. 365(14): p. 1273-1283.

10. Slamon, D.J., et al., Use of Chemotherapy plus a Monoclonal Antibody against HER2 for Metastatic Breast Cancer That Overexpresses HER2. New England Journal of Medicine, 2001. 344(11): p. 783-792.

11. Rugo, H.S., et al., Effect of a Proposed Trastuzumab Biosimilar Compared With Trastuzumab on Overall Response Rate in Patients With ERBB2 (HER2)-Positive Metastatic Breast Cancer: A Randomized Clinical Trial. JAMA, 2017. 317(1): p. 37-47.

12. Fu, C., J. Stebbing, and F.J. Esteva, Clinical development of CT-P6 in HER2 positive breast cancer. Expert Opinion on Biological Therapy, 2019. 19(10): p. 987-992.

13. Jeong, S.A., et al., Mechanism of action of the trastuzumab biosimilar CT-P6. Expert Opinion on Biological Therapy, 2019. 19(10): p. 1085-1095.

14. Lamb, Y.N., SB3 (Ontruzant $\left.{ }^{\circledR}\right)$ : A Trastuzumab Biosimilar. BioDrugs, 2018. 32(3): p. 293-296.

15. Dhillon, S., ABP 980: A Trastuzumab Biosimilar. BioDrugs, 2018. 32(5): p. 511-514.

16. Paik, J., PF-05280014: A Trastuzumab Biosimilar. BioDrugs, 2018. 32(5): p. 515-518.

17. Us Food and Drug Administration. FDA approves first biosimilar for the treatment of certain breast and stomach cancers 2017 [cited 20171 December]; Available from: 
https://www.fda.gov/NewsEvents/Newsroom/PressAnnouncements/ucm587378.htm.

18. Chtioui, H., et al., A bioequivalence study for Hercules, a biosimilar trastuzumab candidate in development. Poster presented at: Pharmacology, 2015: p. 15-17.

19. Waller, C.F., et al., A pharmacokinetics phase 1 bioequivalence study of the trastuzumab biosimilar MYL-14010 vs. EU-trastuzumab and US-trastuzumab. British Journal of Clinical Pharmacology, 2018. 84(10): p. 2336-2343.

20. Gianni, L., et al., Efficacy and safety of neoadjuvant pertuzumab and trastuzumab in women with locally advanced, inflammatory, or early HER2-positive breast cancer (NeoSphere): a randomised multicentre, open-label, phase 2 trial. The Lancet Oncology, 2012. 13(1): p. 25-32.

21. Gianni, L., et al., 5-year analysis of neoadjuvant pertuzumab and trastuzumab in patients with locally advanced, inflammatory, or early-stage HER2-positive breast cancer (NeoSphere): a multicentre, open-label, phase 2 randomised trial. The Lancet Oncology, 2016. 17(6): p. 791-800.

22. Swain, S.M., et al., Pertuzumab, Trastuzumab, and Docetaxel in HER2-Positive Metastatic Breast Cancer. New England Journal of Medicine, 2015. 372(8): p. 724-734.

23. US Food and Drug Administration. Biosimilars. 2021 [cited 20211 December]; Available from: https://www.fda.gov/drugs/therapeutic-biologics-applications-bla/biosimilars.

24. Swain, S.M., et al., Pertuzumab, trastuzumab, and standard anthracycline- and taxane-based chemotherapy for the neoadjuvant treatment of patients with HER2-positive localized breast cancer (BERENICE): a phase II, open-label, multicenter, multinational cardiac safety study. Ann Oncol, 2018. 29(3): p. 646-653.

25. Swain, S.M., et al., Pathologic complete response and outcomes by intrinsic subtypes in NSABP B-41, a randomized neoadjuvant trial of chemotherapy with trastuzumab, lapatinib, or the combination. Breast Cancer Res Treat, 2019. 178(2): p. 389-399.

26. Rugo, H.S., et al., Correlation between week 24 trastuzumab-dkst response and week 48 progression-free survival: the HERITAGE trial. The Breast, 2021. 58: p. 18-26.

27. Bria, E. and P. Conte, Biosimilars as a strategy to improve sustainability. ESMO Open, 2017. 2(2).

28. Li, J., et al., Disparities of Trastuzumab Use in Resource-Limited or Resource-Abundant Regions and Its Survival Benefit on HER2 Positive Breast Cancer: A Real-World Study from China. The Oncologist, 2017. 22(11): p. 1333-1338.

29. Alves, L., et al., Abstract OT2-01-05: A prospective real-world national study to evaluate the efficacy and safety of adjuvant biosimilar trastuzumab in the treatment of HER2-positive breast cancer. Cancer Research, 2020. 80(4 Supplement): p. 0T2-01-05. 


\section{Declarations}

This study was approved by Mersin University Ethics Committee. The author declare no competing interests.

\section{Tables}

Tablo1.Basal Characteristics 


\begin{tabular}{|c|c|c|c|c|c|c|c|c|c|c|c|c|}
\hline & \multicolumn{4}{|c|}{ NEOADJUVANT } & \multicolumn{4}{|c|}{ ADJUVANT } & \multicolumn{4}{|c|}{$\begin{array}{l}\text { METASTATIC } \\
\text { DİSEASE }\end{array}$} \\
\hline & $\begin{array}{l}\text { RTZ } \\
(\mathrm{n}: 40)\end{array}$ & $\begin{array}{l}\text { Myl- } \\
14010 \\
(n: 55)\end{array}$ & $\begin{array}{l}\text { Total } \\
(\mathrm{n}: 92)\end{array}$ & $\mathrm{P}$ & $\begin{array}{l}\text { RTZ } \\
(n: 40)\end{array}$ & $\begin{array}{l}\text { Myl- } \\
14010 \\
(\mathrm{~N}: 26)\end{array}$ & $\begin{array}{l}\text { Total } \\
(\mathrm{n}: 67)\end{array}$ & $P$ & $\begin{array}{l}\text { RTZ } \\
(\mathrm{n}: 40)\end{array}$ & $\begin{array}{l}\text { Myl- } \\
14010 \\
(\mathrm{n}: 24)\end{array}$ & $\begin{array}{l}\text { Total } \\
(\mathrm{n}: 53)\end{array}$ & $P$ \\
\hline Age & 50 & 55 & 52 & 0.57 & 49.0 & 54 & 51 & 0.97 & 50 & 55 & 51 & 0.13 \\
\hline \multicolumn{13}{|l|}{ Stage $4, \mathrm{n}(\%)$} \\
\hline De novo & & & & & & & & & $\begin{array}{l}21 \\
(75) \\
\end{array}$ & $\begin{array}{l}20 \\
(80) \\
\end{array}$ & $\begin{array}{l}41 \\
(77.4) \\
\end{array}$ & \\
\hline Recurren & & & & & & & & & $\begin{array}{l}7 \\
(25) \\
\end{array}$ & $\begin{array}{l}5 \\
(20) \\
\end{array}$ & $\begin{array}{l}12 \\
(22.6) \\
\end{array}$ & \\
\hline $\begin{array}{l}\text { Histology, } \\
\mathrm{n}(\%)\end{array}$ & \multicolumn{4}{|c|}{$\mathrm{P}=0.968$} & \multicolumn{4}{|c|}{$P=0,790$} & \multicolumn{4}{|c|}{$\mathrm{P}=0.893$} \\
\hline $\begin{array}{l}\text { İnvaziv } \\
\text { ductal }\end{array}$ & $\begin{array}{l}29 \\
(87.8)\end{array}$ & $\begin{array}{l}51 \\
(86.4)\end{array}$ & $\begin{array}{l}80 \\
(87.0)\end{array}$ & & $\begin{array}{l}36 \\
(90.0)\end{array}$ & $\begin{array}{l}23 \\
(85.2)\end{array}$ & $\begin{array}{l}59 \\
(88)\end{array}$ & & $\begin{array}{l}25 \\
(89.2)\end{array}$ & $\begin{array}{l}22 \\
(88)\end{array}$ & $\begin{array}{l}47 \\
(88.6)\end{array}$ & \\
\hline İnvaziv lobular & $\begin{array}{l}2 \\
(6.1)\end{array}$ & $\begin{array}{l}5 \\
(8.5)\end{array}$ & $\begin{array}{l}7 \\
(7.6)\end{array}$ & & $\begin{array}{l}3 \\
(7.5)\end{array}$ & $\begin{array}{l}3 \\
(11.1)\end{array}$ & $\begin{array}{l}6 \\
(9)\end{array}$ & & $\begin{array}{l}2 \\
(7.2)\end{array}$ & $\begin{array}{l}2 \\
(8)\end{array}$ & $\begin{array}{l}4 \\
(7,6)\end{array}$ & \\
\hline Other & $\begin{array}{l}2 \\
(6.1)\end{array}$ & $\begin{array}{l}3 \\
(5.1)\end{array}$ & $\begin{array}{l}5 \\
(5.4)\end{array}$ & & $\begin{array}{l}1 \\
(2.5)\end{array}$ & $\begin{array}{l}1 \\
(3.7)\end{array}$ & $\begin{array}{l}2 \\
(3)\end{array}$ & & $\begin{array}{l}1 \\
(3.6)\end{array}$ & $\begin{array}{l}1 \\
(4)\end{array}$ & $\begin{array}{l}2 \\
(3.8)\end{array}$ & \\
\hline $\mathrm{ER}, \mathrm{n}(\%)$ & \multicolumn{4}{|c|}{$\mathrm{P}=0.385$} & \multicolumn{4}{|c|}{$\mathrm{P}=0.545$} & \multicolumn{4}{|c|}{$\mathrm{P}=0.552$} \\
\hline Positive & $\begin{array}{l}19 \\
(57.6) \\
\end{array}$ & $\begin{array}{l}27 \\
(45.8) \\
\end{array}$ & $\begin{array}{l}46 \\
(50) \\
\end{array}$ & & $\begin{array}{l}17 \\
(42.5) \\
\end{array}$ & $\begin{array}{l}11 \\
(40.7) \\
\end{array}$ & $\begin{array}{l}28 \\
(41.8) \\
\end{array}$ & & $\begin{array}{l}14 \\
(50)\end{array}$ & $\begin{array}{l}12 \\
(48) \\
\end{array}$ & $\begin{array}{l}26 \\
(49.1) \\
\end{array}$ & \\
\hline Negative & $\begin{array}{l}14 \\
(42.4) \\
\end{array}$ & $\begin{array}{l}32 \\
(54.2) \\
\end{array}$ & $\begin{array}{l}46 \\
(50) \\
\end{array}$ & & $\begin{array}{l}23 \\
(57.5) \\
\end{array}$ & $\begin{array}{l}16 \\
(59.3) \\
\end{array}$ & $\begin{array}{l}39 \\
(58.2) \\
\end{array}$ & & $\begin{array}{l}14 \\
(50)\end{array}$ & $\begin{array}{l}13 \\
(52) \\
\end{array}$ & $\begin{array}{l}27 \\
(50.9) \\
\end{array}$ & \\
\hline $\mathrm{PR}, \mathrm{n}(\%)$ & \multicolumn{4}{|c|}{$\mathrm{P}=0.514$} & \multicolumn{4}{|c|}{$\mathrm{P}=0.804$} & \multicolumn{4}{|c|}{$\mathrm{P}=0.168$} \\
\hline Positive & $\begin{array}{l}15 \\
(45.4)\end{array}$ & $\begin{array}{l}28 \\
(47.4)\end{array}$ & $\begin{array}{l}43 \\
(46.7)\end{array}$ & & $\begin{array}{l}18 \\
(45)\end{array}$ & $\begin{array}{l}11 \\
(40.7)\end{array}$ & $\begin{array}{l}29 \\
(43.3)\end{array}$ & & $\begin{array}{l}8 \\
(28.6)\end{array}$ & $\begin{array}{l}12 \\
(48)\end{array}$ & $\begin{array}{l}20 \\
(37.7)\end{array}$ & \\
\hline Negative & $\begin{array}{l}18 \\
(54.6) \\
\end{array}$ & $\begin{array}{l}31 \\
(52.6) \\
\end{array}$ & $\begin{array}{l}49 \\
(53.3) \\
\end{array}$ & & $\begin{array}{l}22 \\
(55) \\
\end{array}$ & $\begin{array}{l}16 \\
(59.3) \\
\end{array}$ & $\begin{array}{l}8 \\
(56.7) \\
\end{array}$ & & $\begin{array}{l}20 \\
(71.4) \\
\end{array}$ & $\begin{array}{l}13 \\
(52) \\
\end{array}$ & $\begin{array}{l}33 \\
(62.3) \\
\end{array}$ & \\
\hline Subgrup, n (\%) & \multicolumn{4}{|c|}{$\mathrm{P}=0.669$} & \multicolumn{4}{|c|}{$\mathrm{P}=0.211$} & \multicolumn{4}{|c|}{$\mathrm{P}=0.583$} \\
\hline $\mathrm{HR}+/ \mathrm{HER} 2+$ & $\begin{array}{l}19 \\
(57.6)\end{array}$ & $\begin{array}{l}31 \\
(52.5)\end{array}$ & $\begin{array}{l}50 \\
(54.3)\end{array}$ & & $\begin{array}{l}25 \\
(62.5)\end{array}$ & $\begin{array}{l}12 \\
(44.4)\end{array}$ & $\begin{array}{l}37 \\
(55.2)\end{array}$ & & $\begin{array}{l}14 \\
(50)\end{array}$ & $\begin{array}{l}15 \\
(60)\end{array}$ & $\begin{array}{l}29 \\
(54.7)\end{array}$ & \\
\hline HR-/HER2+ & $\begin{array}{l}14 \\
(42.4) \\
\end{array}$ & $\begin{array}{l}28 \\
(47.5) \\
\end{array}$ & $\begin{array}{l}42 \\
(45.7)\end{array}$ & & $\begin{array}{l}15 \\
(37.5) \\
\end{array}$ & $\begin{array}{l}15 \\
(55.6) \\
\end{array}$ & $\begin{array}{l}30 \\
(44.8) \\
\end{array}$ & & $\begin{array}{l}14 \\
(50)\end{array}$ & $\begin{array}{l}10 \\
(40)\end{array}$ & $\begin{array}{l}24 \\
(45.3) \\
\end{array}$ & \\
\hline HG, n (\%) & \multicolumn{4}{|c|}{$\mathrm{P}=0.789$} & \multicolumn{4}{|c|}{$\mathrm{P}=0.778$} & \multicolumn{4}{|c|}{$\mathrm{P}=0.358$} \\
\hline 1,2 & $\begin{array}{l}6 \\
(18.2) \\
\end{array}$ & $\begin{array}{l}13 \\
(22) \\
\end{array}$ & $\begin{array}{l}19 \\
(20.7) \\
\end{array}$ & & $\begin{array}{l}10 \\
(25.0) \\
\end{array}$ & $\begin{array}{l}8 \\
(29.6) \\
\end{array}$ & $\begin{array}{l}18 \\
(26.7) \\
\end{array}$ & & $\begin{array}{l}4 \\
(14.3) \\
\end{array}$ & $\begin{array}{l}2 \\
(8) \\
\end{array}$ & $\begin{array}{l}6 \\
(11.3) \\
\end{array}$ & \\
\hline 3 & $\begin{array}{l}27 \\
(81.8) \\
\end{array}$ & $\begin{array}{l}46 \\
(78.2) \\
\end{array}$ & $\begin{array}{l}73 \\
(79.3)\end{array}$ & & $\begin{array}{l}30 \\
(75.0)\end{array}$ & $\begin{array}{l}19 \\
(70.4)\end{array}$ & $\begin{array}{l}49 \\
(73.3)\end{array}$ & & $\begin{array}{l}24 \\
(85.7)\end{array}$ & $\begin{array}{l}23 \\
(92)\end{array}$ & $\begin{array}{l}47 \\
(78.7)\end{array}$ & \\
\hline Ki67, n (\%) & \multicolumn{4}{|c|}{$P=0.609$} & \multicolumn{4}{|c|}{$\mathrm{P}=0.730$} & \multicolumn{4}{|c|}{$P=0.528$} \\
\hline$<14$ & $\begin{array}{l}3 \\
(9.1)\end{array}$ & $\begin{array}{l}6 \\
(10.2)\end{array}$ & $\begin{array}{l}9 \\
(9.8)\end{array}$ & & $\begin{array}{l}6 \\
(15.0)\end{array}$ & $\begin{array}{l}3 \\
(11.1)\end{array}$ & $\begin{array}{l}9 \\
(13.4)\end{array}$ & & $\begin{array}{l}1 \\
(3.6)\end{array}$ & $\begin{array}{l}0 \\
(0.0)\end{array}$ & $\begin{array}{l}1 \\
(1.5)\end{array}$ & \\
\hline$\geq 14$ & $\begin{array}{l}30 \\
(90.9)\end{array}$ & $\begin{array}{l}53 \\
(89.8)\end{array}$ & $\begin{array}{l}83 \\
(90.2)\end{array}$ & & $\begin{array}{l}34 \\
(85.0)\end{array}$ & $\begin{array}{l}24 \\
(88.9)\end{array}$ & $\begin{array}{l}58 \\
(86.6)\end{array}$ & & $\begin{array}{l}27 \\
(96.4)\end{array}$ & $\begin{array}{l}25 \\
(100)\end{array}$ & $\begin{array}{l}52 \\
(98.5)\end{array}$ & \\
\hline $\mathrm{cT}^{\mathrm{b}}, \mathrm{n}(\%)$ & \multicolumn{4}{|c|}{$\mathrm{P}=0.654$} & \multicolumn{4}{|c|}{$\mathrm{P}=0.328$} & \multicolumn{4}{|c|}{$P=0.625$} \\
\hline
\end{tabular}




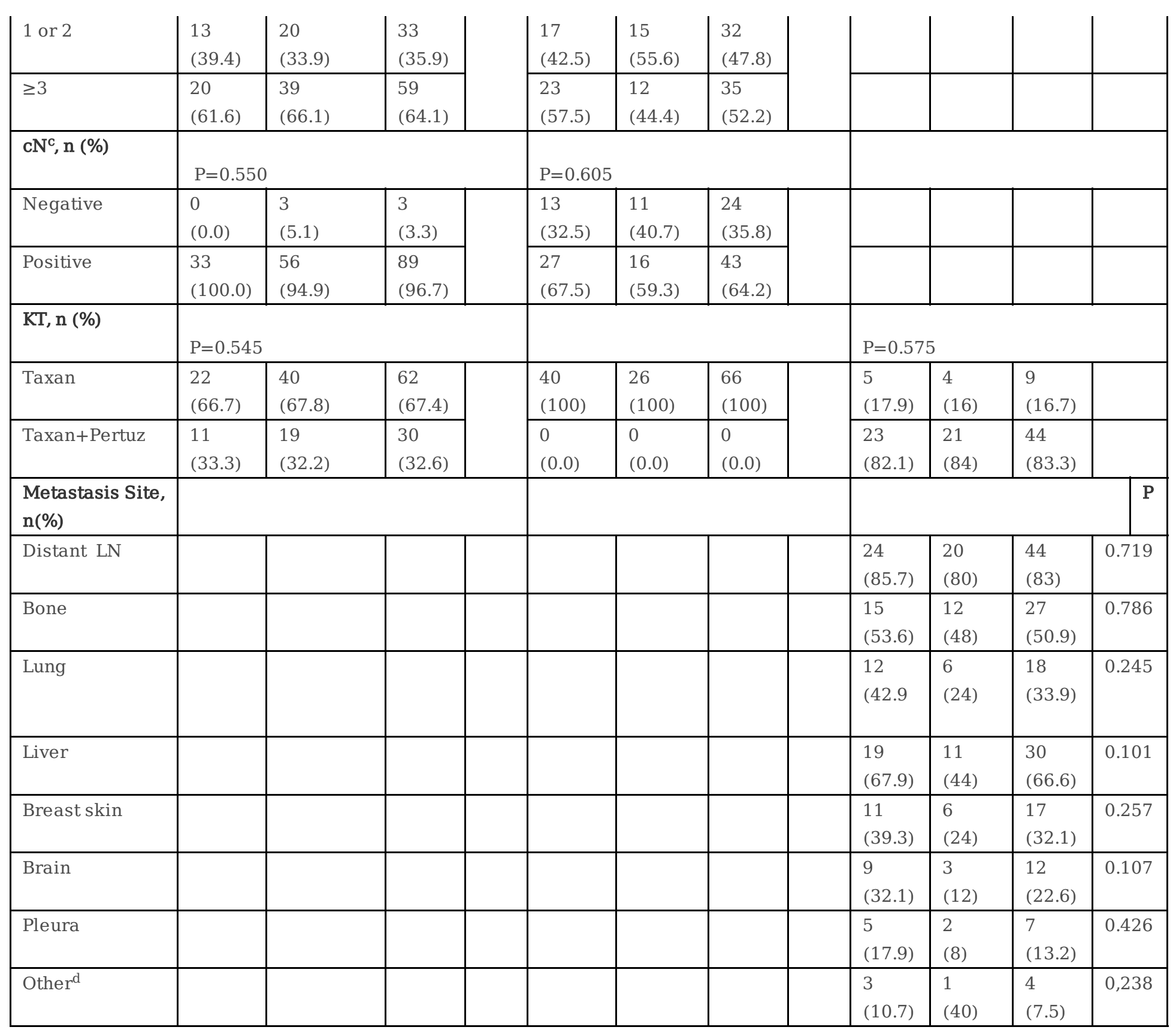

\footnotetext{
${ }^{\mathrm{a}}$ : Other histology; micropapiller, apocrine, mucinous and metaplastic carcinoma

$\mathrm{b}_{\text {: }} \mathrm{cT}$ : was based on tumor size measured by pre-treatment breast magnetic resonance imaging

C: $\mathrm{CN}$ : positive was defined as axillary lymph node metastasis proven by fine-needle aspiration biopsy (FNAB, or suspicious axillary lymph node metastasis in the imaging study among patients who did not receive FNAB.

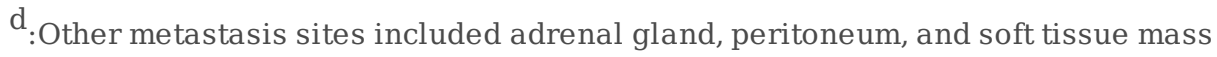

cN; clinical node stage, cT; clinical tumor stage, ER; estrogen receptor, HER2; human epidermal growth factor receptor 2, HG; histologic grade, HR; hormon receptor, LN; lymph node, PR; progesteron receptor, RTZ; reference trastuzumab
}

TABLE 2.Best Overall Response based on RECIST 1.1 criteria, according to palliative treatment in patients with HER2 (+) MBC 


\begin{tabular}{|c|c|c|c|c|c|c|c|c|c|}
\hline & \multicolumn{3}{|c|}{ ALL PATIENTS } & \multicolumn{3}{|c|}{ HR+/HER2+ } & \multicolumn{3}{|c|}{ HR-/HER2+ } \\
\hline & $\begin{array}{l}\text { RTZ } \\
(40)\end{array}$ & $\begin{array}{l}\text { Myl-1401O } \\
(24)\end{array}$ & $P$ & $\begin{array}{l}\text { RTZ } \\
(23)\end{array}$ & $\begin{array}{l}\text { Myl-1401O } \\
(14)\end{array}$ & $\mathrm{P}$ & $\begin{array}{l}\text { RTZ } \\
(17)\end{array}$ & $\begin{array}{l}\text { Myl-1401O } \\
\text { (10) }\end{array}$ & $\mathrm{P}$ \\
\hline Response & \multicolumn{3}{|l|}{$0.540^{\mathrm{a}}$} & \multicolumn{3}{|l|}{$0.113^{\mathrm{a}}$} & \multicolumn{3}{|l|}{$0.529^{a}$} \\
\hline $\mathrm{CR}, \mathrm{n}(\%)$ & $\begin{array}{l}10 \\
(35.7)\end{array}$ & $\begin{array}{l}12 \\
(48)\end{array}$ & & $\begin{array}{l}3 \\
(21.4)\end{array}$ & $\begin{array}{l}8 \\
(53.3)\end{array}$ & & $\begin{array}{l}7 \\
(50)\end{array}$ & $\begin{array}{l}4 \\
(40)\end{array}$ & \\
\hline PR, n (\%) & $\begin{array}{l}12 \\
(42.9)\end{array}$ & $\begin{array}{l}9 \\
(36)\end{array}$ & & $\begin{array}{l}8 \\
(57.1)\end{array}$ & $\begin{array}{l}5 \\
(33.3)\end{array}$ & & $\begin{array}{l}4 \\
(28.6)\end{array}$ & $\begin{array}{l}4 \\
(40)\end{array}$ & \\
\hline $\mathrm{SD}, \mathrm{n}(\%)$ & $\begin{array}{l}3 \\
(10.7)\end{array}$ & $\begin{array}{l}2 \\
(8)\end{array}$ & & $\begin{array}{l}0 \\
(0)\end{array}$ & $\begin{array}{l}1 \\
(6.7)\end{array}$ & & $\begin{array}{l}3 \\
(21.4)\end{array}$ & $\begin{array}{l}1 \\
(10)\end{array}$ & \\
\hline PD, n (\%) & $\begin{array}{l}3 \\
(10.7)\end{array}$ & $\begin{array}{l}2 \\
(8)\end{array}$ & & $\begin{array}{l}3 \\
(21.4) \\
\end{array}$ & $\begin{array}{l}1 \\
(6.7)\end{array}$ & & $\begin{array}{l}0 \\
(0)\end{array}$ & $\begin{array}{l}1 \\
(10)\end{array}$ & \\
\hline $\begin{array}{l}\text { Overall Response Rate } \\
\text { (ORR) }\end{array}$ & \multicolumn{3}{|l|}{$0.732^{\mathrm{a}}$} & \multicolumn{3}{|l|}{$0.465^{\mathrm{a}}$} & \multicolumn{3}{|l|}{$0.668^{\mathrm{a}}$} \\
\hline CR, PR, n (\%) & $\begin{array}{l}22 \\
(78.6) \\
\end{array}$ & $\begin{array}{l}21 \\
(84)\end{array}$ & & $11(78.5)$ & 13(86.6) & & 11(78.5) & $8(80)$ & \\
\hline $\begin{array}{l}\text { Disease Control Rate } \\
\text { (DCR) }\end{array}$ & \multicolumn{3}{|l|}{$0.555^{\mathrm{a}}$} & \multicolumn{3}{|l|}{$0.330^{\mathrm{a}}$} & \multicolumn{3}{|l|}{$0.417^{\mathrm{a}}$} \\
\hline CR, PR, SD, n (\%) & $25(89.3)$ & $23(92)$ & & $11(78.5)$ & $14(93.3)$ & & $14(100)$ & $9(90)$ & \\
\hline
\end{tabular}

\section{${ }^{\mathrm{a}}$ : Fischer exact test}

$\mathrm{CR}$, complete response; HER2, human epidermal growth factor receptor 2; HR, hormon receptor; MBC, metastatic breast cancer; $\mathrm{PD}$, progressive disease; PR, partial response; RTZ, referans trastuzumab; SD, stabil disease

Table3. Myl-14010 (Trastuzumab biosimilar) and Trastuzumab Drug Safety Comparison

\begin{tabular}{|c|c|c|c|c|c|c|c|c|c|c|c|c|}
\hline & \multicolumn{4}{|c|}{ NEOADJUVANT } & \multicolumn{4}{|c|}{ ADJUVANT } & \multicolumn{4}{|c|}{ METASTATİC } \\
\hline & $\begin{array}{l}\text { RTZ } \\
(\mathrm{n}: 33)\end{array}$ & $\begin{array}{l}\text { Myl- } \\
14010 \\
(n: 59)\end{array}$ & $\begin{array}{l}\text { Total } \\
(\mathrm{n}: 92)\end{array}$ & $\mathrm{P}$ & $\begin{array}{l}\text { RTZ } \\
(\mathrm{n}: 40)\end{array}$ & $\begin{array}{l}\text { Myl- } \\
14010 \\
(n: 27)\end{array}$ & $\begin{array}{l}\text { Total } \\
(\mathrm{n}: 67)\end{array}$ & $\mathrm{P}$ & $\begin{array}{l}\text { RTZ } \\
(\mathrm{n}: 28)\end{array}$ & $\begin{array}{l}\text { Myl- } \\
14010 \\
(n: 25)\end{array}$ & $\begin{array}{l}\text { Total } \\
(\mathrm{n}: 53)\end{array}$ & $\mathrm{P}$ \\
\hline $\begin{array}{l}\text { Drug reaction, } \\
\mathrm{n}(\%)\end{array}$ & $\begin{array}{l}1 \\
(3)\end{array}$ & $\begin{array}{l}5 \\
(8.4)\end{array}$ & $\begin{array}{l}7 \\
(6.5)\end{array}$ & $0.41^{\mathrm{a}}$ & $\begin{array}{l}4 \\
(10.0)\end{array}$ & $\begin{array}{l}3 \\
(11.1)\end{array}$ & $\begin{array}{l}7 \\
(10.6)\end{array}$ & $0.59^{\mathrm{a}}$ & $\begin{array}{l}2 \\
(7.1)\end{array}$ & $\begin{array}{l}2 \\
(8.0)\end{array}$ & $\begin{array}{l}4 \\
(7.5)\end{array}$ & $0.55^{\mathrm{a}}$ \\
\hline $\begin{array}{l}\text { Cardiotoxity, } \\
\text { n (\%) }\end{array}$ & $\begin{array}{l}6 \\
(18.1)\end{array}$ & $\begin{array}{l}5 \\
(8.9)\end{array}$ & $\begin{array}{l}13 \\
(11.9)\end{array}$ & $0.19^{\mathrm{a}}$ & $\begin{array}{l}3 \\
(7.5)\end{array}$ & $\begin{array}{l}3 \\
(11.1)\end{array}$ & $\begin{array}{l}6 \\
(8.9)\end{array}$ & $0.67^{\mathrm{a}}$ & $\begin{array}{l}4 \\
(14.2)\end{array}$ & $\begin{array}{l}5 \\
(20)\end{array}$ & $\begin{array}{l}9 \\
(16.9)\end{array}$ & $0.71^{\mathrm{a}}$ \\
\hline
\end{tabular}

a : Fischer Exact Test, RTZ: Reference trastuzumab, Myl-1401O: Trastuzumab biosimilar, Cardiyotoksisite: $\geq 10 \%$ EF decrease or $\mathrm{EF}<\% 50$

Figures 


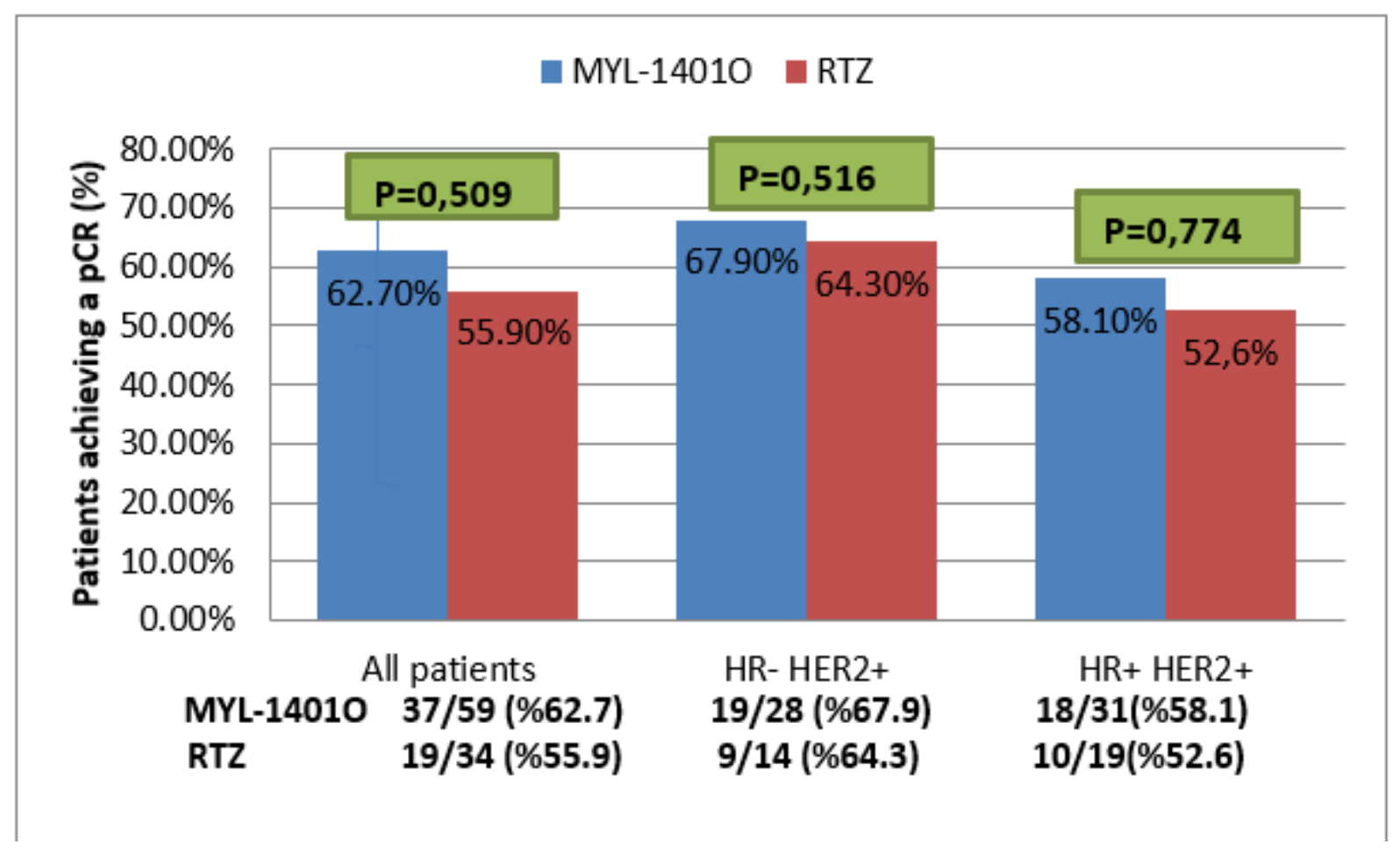

\section{Figure 1}

Percentage of patients with HER2-positive early-stage (neoadjuvant) breast cancer who achieved a pCR following MYL-14010 or RTZ treatment, stratified by HR status for all patients. HER2, human epidermal growth factor receptor 2; HR, hormone receptor; $\mathrm{PCR}$, pathologic complete response; RTZ, reference trastuzumab 


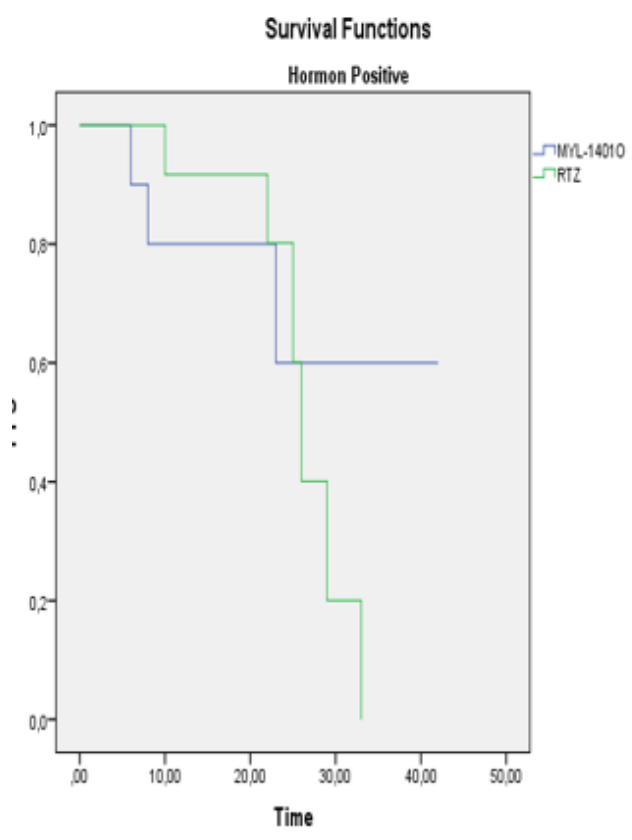

A: HR(+)/HER2(+)

$\log$ rank $\mathrm{p}=0.387$

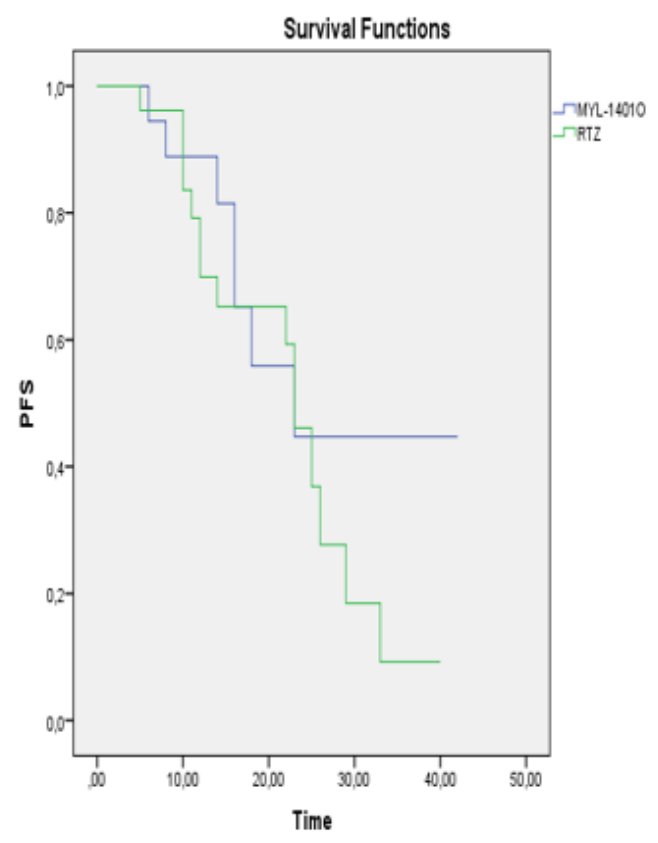

C: All Patients

$\log \operatorname{rank} \mathrm{p}=0.270$

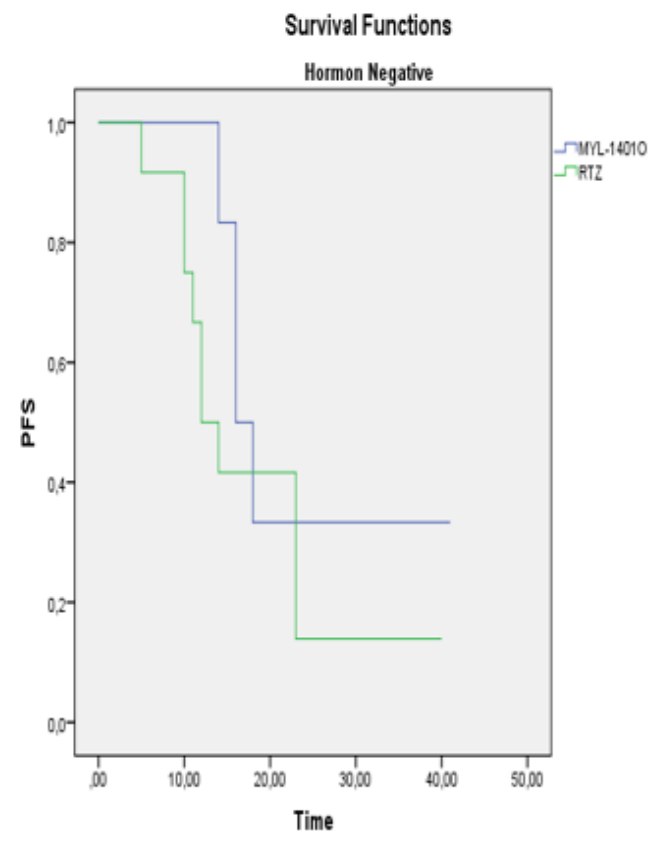

B: HR(-)/HER2(+)

$\log \operatorname{rank} \mathrm{p}=0.376$

\section{Figure 2}

PFS for HER2-positive metastatic breast cancer patients who received palliative treatment with MYL14010 or RTZ. HER2, human epidermal growth factor receptor 2; HR, hormon receptor; PFS, progressionfree survival; RTZ, reference trastuzumab 